\title{
PENGARUH CURRENT RATIO, DEBT TO EQUITY RATIO, DAN RETURN ON ASSETS TERHADAP KEBIJAKAN DEVIDEN PADA PERUSAHAAN PROPERTY DAN REAL ESTATE YANG TERDAFTAR DI BURSA EFEK INDONESIA
}

\author{
THE EFFECT OF CURRENT RATIO, DEBT TO EQUITY RATIO, AND \\ RETURN ON ASSETS ON DIVIDEND POLICY AT PROPERTY AND REAL \\ ESTATE COMPANIES THAT LISTED ON INDONESIA STOCK EXCHANGE
}

\author{
Enda Noviyanti Simorangkir ${ }^{1}$, Teguh Hakim Prajoggi ${ }^{2}$, \\ Enzelina $^{3}$, Edo Hasugian ${ }^{4}$, Desy ${ }^{5}$ \\ Universitas Prima Indonesia, Medan ${ }^{1,2,3,4,5}$ \\ teguhhakim99@gmail.com²
}

\begin{abstract}
In investing capital an investor needs a company's financial statements that will help in making investment decisions. This study aims to analyze and test the effect of the current ratio, debt to equity ratio, return on assets on dividend payout ratios in property and real estate companies listed on the Indonesia Stock Exchange (IDX) for the 2015-2017 period. The research method in this study uses a quantitative approach. There were 46 companies that were used as populations in this study and by using a purposive sampling technique 13 samples were also obtained. The data analysis testing method used is multiple linear regression analysis using the classic assumption test. The results of this study show that the current ratio, debt to equity ratio, and return on assets have a simultaneous effect on dividend policy on property and real estate companies listed on the IDX for the 2015-2017 period with a Fcount value of 4.309> Ftable of 2, 87. Partially the debt to equity ratio, return on assets has no effect on dividend policy while the current ratio partially has a positive effect on dividend policy. The results of the analysis of the coefficient of determination show the Adjusted $R 2$ value of 0.207 , meaning that the variation in the variable dividend payout ratio can be explained by variations in the current ratio variable, debt to equity ratio and return on assets by $20.7 \%$ while the remaining $70.3 \%$, is described by other variables outside research.
\end{abstract}

Keywords: Current Ratio (CR), Debt to Equity Ratio (DER), Return on Assets (ROA) and dividend policy

\footnotetext{
ABSTRAK

Dalam menanamkan modalnya seorang investor memerlukan laporan keuangan suatu perusahaan yang akan membantu dalam membuat keputusan berinvestasi. Penelitian ini memiliki tujuan untuk menganalisa dan menguji pengaruh current ratio, debt to equity ratio, return on assets terhadap kebijakan dividen (dividend payout ratio) pada perusahaan sektor property dan real estate yang terdaftar di BEI (Bursa Efek Indonesia) untuk periode 2015-2017. Metode penelitian dalam penelitian ini menggunakan pendekatan secara kuantitatif. Terdapat 46 perusahaan yang dijadikan sebagai populasi dalam penelitian ini dan dengan menggunakan teknik pengambilan sample purposive sampling diperoleh pula sampel sebanyak 13 perusahaan. Metode
} 
pengujian analisis data yang digunakan adalah analisis regresi linier berganda dengan memakai uji asumsi klasik. Hasil dari penelitian ini memperlihatkan bahwa current ratio, debt to equity ratio, dan return on assets memiliki pengaruh secara simultan terhadap kebijakan dividen pada perusahaan property dan real estate yang terdaftar di

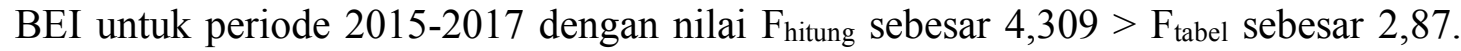
Secara parsial debt to equity ratio, return on assets tidak berpengaruh terhadap kebijakan dividen sedangkan current ratio secara parsial berpengaruh positif terhadap kebijakan dividen. Hasil analisis koefisien determinasi memperlihatkan nilai Adjusted $\mathrm{R}^{2}$ sebesar 0,207, artinya variasi variabel dividend payout ratio yang dapat diterangkan oleh variasi variabel current ratio, debt to equity ratio dan return on assets sebesar 20,7\% sedangkan 70,3\% sisanya, dideskripsikan oleh variabel lainnya diluar penelitian.

Kata Kunci: Current Ratio (CR), Debt to Equity Ratio (DER), Return on Assets (ROA) dan kebijakan dividen

\section{PENDAHULUAN}

Pertumbuhan bisnis di dunia saat ini berkembang dengan cukup pesat, banyak perusahaan yang berusaha untuk menarik perhatian para investor karena investor merupakan salah satu dari beberapa faktor yang menentukan tingkat pertumbuhan suatu perusahaan. Dalam menanamkan modalnya seorang investor memerlukan laporan keuangan suatu perusahaan yang akan membantu dalam membuat keputusan berinvestasi. Para investor melakukan investasi dengan mengharapkan pendapatan atau tingkat pengembalian berupa cash dividend.

Besarnya dividen yang akan dibagikan ditentukan dalam Rapat Umum Pemegang Saham (RUPS). Untuk mengurangi ketidakpastian investasi maka pihak perusahaan membuat suatu kebijakan mengenai pembayaran dividen, dimana kebijakan ini kita kenal sebagai kebijakan dividen. Kebijakan dividen menentukan apakah laba yang diperoleh perusahaan akhir tahun akan dibagi kepada pemegang saham dalam bentuk dividen atau akan ditahan untuk menambah modal. Indikator yang akan digunakan untuk mengukur kebijakan dividen dalam penelitian ini adalah rasio pembayaran dividen (DPR/Dividend Payout Ratio). Perusahaan yang akan digunakan dalam penelitian ini yaitu perusahaan property dan real estate mulai dari tahun 2015-2017. Alasan penelitian ini menggunakan perusahaan property dan real estate yaitu perusahaan property dan real estate memiliki prospek yang bagus di masa yang akan datang dengan melihat potensi banyaknya pembangunan yang terjadi dan jumlah penduduk yang terus bertambah banyak selain itu dalam menjalankan usahanya, perusahaan property dan real estate memerlukan modal yang cukup besar sehingga perusahaan tersebut pasti akan berusaha untuk menambah modal dengan memperbaiki kinerjanya. Dalam penelitian ini, faktor-faktor yang akan penulis teliti antara lain current ratio, debt to equity ratio, dan return on assets.

Current ratio pada PT Ciputra Development Tbk untuk tahun 2016 mengalami kenaikan sebesar 8,5\% dari tahun 2015 sedangkan dividen kas yang dibagikan pada tahun 2016 tersebut mengalami penurunan sebesar $4,47 \%$. Hal yang sama juga dapat dilihat pada PT Intiland Development 
Tbk, dan PT Lippo Karawaci Tbk. Keadaan yang demikian tidak sesuai dengan teori yang menyatakan apabila current ratio meningkat maka pengembalian dividen kas juga meningkat.

Debt to equity ratio pada $\mathrm{PT}$ Intiland Development Tbk tahun 2017 debt to equity ratio mengalami peningkatan sebesar $0,05 \%$ yang diikuti dengan peningkatan dividen kas sebesar $0,95 \%$ pada periode tersebut. Hal yang sama juga dapat dilihat pada PT Ciputra Development Tbk, dan PT Lippo Karawaci Tbk. Hal tersebut tidak sesuai dengan teori yang menyatakan apabila debt to equity ratio meningkat maka dividen yang dibagikan menurun.

Return on assets pada PT Lippo Karawaci Tbk return on assets tahun 2016 mengalami peningkatan sebesar $16,55 \%$ sedangkan dividen kas menurun sebesar $81,08 \%$. Hal yang sama juga terjadi pada PT Ciputra Development Tbk, dan PT Intiland Development Tbk. Hal ini tidak sesuai dengan teori yang menyatakan apabila return on asset meningkat maka dividen yang dibagikan juga akan meningkat.

Hery (2016), current ratio (CR) digunakan untuk memperkirakan atau menghitung kemampuan perusahaan dalam membayar utang jangka pendeknya yang akan jatuh tempo dengan aktiva lancar yang tersedia. "Semakin tinggi rasio ini menyimpulkan bahwa semakin likuid perusahaan tersebut dalam memenuhi kewajiban jangka pendeknya" (Sukamulja, 2019). Sari, et al., (2016) menyimpulkan bahwa current ratio berpengaruh positif dan signifikan terhadap kebijakan dividen, sementara Wahyuni (2018) menyimpulkan bahwa current ratio tidak berpengaruh terhadap kebijakan dividen karena tidak ada hubungan yang signifikan antara current ratio dengan kebijakan dividen.

Menurut Sujarweni (2019), debt to equity ratio (DER) adalah rasio yang digunakan untuk membandingkan jumlah proporsi hutang suatu perusahaan terhadap modal yang dimiliki untuk memenuhi seluruh kewajibannya. Menurut Muhammadinah \& Jamil (2016) menyatakan bahwa Peningkatan hutang dapat mempengaruhi besar kecilnya laba bersih yang diperoleh bagi pemegang saham dan dividen yang diterima dikarenakan pembayaran hutang lebih diprioritaskan daripada pembagian dividen.

Jika beban hutang yang ditanggung perusahaan tinggi maka pembayaran dividen akan semakin rendah sehingga debt to equity ratio (DER) berpengaruh negatif terhadap dividend payout ratio. Hasil penelitian dari Pamungkas (2017) juga menyatakan bahwa perusahaan lebih menyukai pembiayaan dengan modal sendiri daripada menggunakan dana dari pihak luar (hutang), karena hutang memberikan risiko yang tinggi. Menurut Atmoko, et al., (2018) Jika persentase rasio debt to equity ratio semakin besar maka semakin besar pula tingkat ketergantungan perusahaan dalam membayar hutang kepada pihak eksternal (kreditur) dikarenakan beban bunga yang semakin besar. Semakin meningkat rasio debt to equity ratio maka hal tersebut menunjukkan bahwa profit yang diperoleh perusahaan menurun, karena sebagian digunakan untuk membayar bunga pinjaman.

Prihadi (2019), return on asset merupakan rasio yang digunakan untuk menunjukkan seberapa besar kontribusi yang diberikan aset perusahaan dalam menghasilkan laba bersih. Rasio ini 
digunakan untuk mengukur efektivitas perusahaan didalam menghasilkan keuntungan dengan memanfaatkan aktiva yang dimilikinya.

Muhammadinah \& Jamil (2016) menyatakan bahwa Persentase Return On Asset (ROA) yang semakin tinggi memungkinkan pembagian deviden yang cukup besar. Selain itu, Sudana (2011) menyimpulkan bahwa semakin besar return on asset, berarti semakin efisien penggunaan aktiva yang dimiliki suatu perusahaan atau dengan kata lain jumlah aktiva yang sama bisa dihasilkan laba yang lebih besar, dan sebaliknya. Penelitian lain juga dilakukan oleh Yudhanto \& Aisjah (2012), yang menyimpulkan hasil bahwa return on assets berpengaruh positif dan signifikan terhadap kebijakan dividen.

Wahyudiono (2014) dividen merupakan laba bersih atau bagian dari keuntungan yang diperoleh perusahaan yang kemudian dibagikan kepada pemegang saham. Dividen sendiri dapat dibagikan dalam bentuk lain selain dividen kas, yaitu dalam bentuk saham (Husnan, 2015). Ada beberapa pertimbangan yang diambil suatu perusahaan sebelum membagikan dividen kepada para pemegang sahamnya, yaitu posisi likuiditas, alternatif pembiayaan lain, pendapatan, kontrol kepemilikan, dan inflasi (Kamaludin, 2012).

\section{METODE PENELITIAN}

Penelitian ini merupakan penelitian yang menggunakan metode kausal dengan tujuan untuk mengetahui bagaimana pengaruh dari variabel-variabel independen yaitu current ratio, return on asset, dan debt to equity ratio terhadap variabel dependennya yaitu Kebijakan Dividen (dividend payout ratio). Jenis data yang digunakan yaitu data sekunder yang diperoleh dari data laporan keuangan perusahaan-perusahaan property dan real estate yang tercatat di Bursa Efek Indonesia pada periode 2015 - 2017.

Populasi yang digunakan dalam penelitian ini adalah semua perusahaan property dan real estate yang terdaftar di Bursa Efek Indonesia untuk periode 2015-2017 yaitu sebanyak 46 perusahaan. Teknik pengambilan sampel yang digunakan oleh peneliti yaitu teknik purposive sampling. Purposive samplingyaitu pemilihan sampel dengan berdasarkan pada kriteria tertentu yang ditetapkan oleh peneliti. Berikut kriteria yang digunakan peneliti dalam pengambilan sampel:

1. Perusahaan property dan real estate yang terdaftar di Bursa Efek Indonesia (BEI) periode 2015 2017.

2. Perusahaan property dan real estate yang menerbitkan laporan keuangan untuk periode $2015-2017$.

3. Perusahaan property dan real estate yang memperoleh laba bersih selama periode 2015-2017.

4. Perusahaan property dan real estate yang membagikan dividen kas setidaknya tiga tahun berturut-turut.

Tabel 1. Tabel Seleksi Sampel Berdasarkan Kriteria

\begin{tabular}{clc}
\hline NO & \multicolumn{1}{c}{ KRITERIA } & JUMLAH \\
\hline 1 & $\begin{array}{l}\text { Perusahaan Property dan Real Estate yang terdaftar di Bursa Efek Indonesia } \\
\text { (BEI) periode 2015-2017 }\end{array}$ & 46 \\
2 & $\begin{array}{l}\text { Perusahaan Property dan Real Estate yang tidak menerbitkan laporan } \\
\text { keuangan untuk periode 2015-2017 }\end{array}$
\end{tabular}


3 Perusahaan Property dan Real Estate yang tidak memperoleh laba bersih selama periode $2015-2017$

4 Perusahaan Property dan Real Estate yang tidak membagikan deviden kas setidaknya tiga tahun berturut-turut Jumlah perusahaan yang memenuhi kriteria

Sumber: www.idx.com

\section{Teknik Analisis Data}

Uji Signifikansi secara Parsial (TTest)

Uji $\mathrm{T}$ atau biasa disebut uji parsial merupakan uji yang memiliki tujuan untuk melihat bagaimana pengaruh atau hubungan setiap variabel bebas secara sendiri-sendiri terhadap variabel terikatnya atau signifikansi antara variabel bebas dengan variabel terikat.Uji ini dapat dilakukan dengan membandingkan antara $t_{\text {tabel }}$ dan $t_{\text {hitung }}$ dengan taraf signifikan yang sudah ditetapkan yaitu 5\%. Apabila hasil dari $t_{\text {hitung }}>t_{\text {tabel }}$ maka variabel bebas secara individual mempunyai pengaruh terhadap variabel terikat.

\section{Uji Signifikansi secara Simultan (F- Test)}

Uji $F$ merupakan uji yang digunakan untuk melihat bagaimana pengaruh atau hubungan antara semua variabel bebas secara bersama-sama terhadap variabel terikat atau apakah model regresi yang dibuat bersifat signifikan/baik atau non signifikan/tidak baik.Uji $F$ ini dilakukan dengan membandingkan antara $F_{\text {tabel }}$ dengan $F_{\text {hitung }}$ dengan taraf signifikan yang sudah ditentukan yaitu 5\%. Apabila $F_{\text {hitung }}>F_{\text {tabel }}$ maka semua variabel bebas berpengaruh secara signifikan terhadap variabel terikat. Apabila $\mathrm{F}_{\text {hitung }}<\mathrm{F}_{\text {tabel }}$ maka semua variabel bebas tidak berpengaruh secara signifikan terhadap variabel bebas.

\section{HASIL DAN PEMBAHASAN}

Uji Signifikansi secara Parsial (TTest)

Uji statistik parsial dilakukan untuk mengetahui bagaimana pengaruh variabel independen secara individual terhadap variabel dependen. Pengujian ini dilakukan dengan melakukan perbandingan antara nilai $t_{\text {hitung }}$ dengan $t_{\text {tabel }}$ dengan menggunakan tingkat kepercayaan $95 \%(\alpha=0.05)$

Formulasi hipotesis:

H0: Variabel current ratio, debt to equity ratio dan return on assets secara parsial tidak berpengaruh terhadap dividend payout ratio.

Ha: Variabel current ratio, debt to equity ratio dan return on assets secara parsial berpengaruh terhadap dividend payout ratio.

Dasar pengambilan keputusannya adalah sebagai berikut:

Jika $t_{\text {hitung }}>t_{\text {tabel, }}$, maka Ha diterima dan H0 ditolak.

Jika $\mathrm{t}_{\text {hitung }}<\mathrm{t}_{\text {tabel, }}$, maka Ha ditolak dan $\mathrm{H} 0$ diterima

Tabel 2 Hasil Uji T-Test

\begin{tabular}{ccc}
\hline Variabel & $\mathrm{t}$ & Sig \\
\hline $\mathrm{X} 1$ & 1.886 & 0.070 \\
\hline $\mathrm{X} 2$ & -0.672 & 0.506 \\
\hline $\mathrm{X} 3$ & 1.345 & 0.187 \\
\hline
\end{tabular}

Sumber : Data Olahan (2020)

Berdasarkan tabel 2 di atas maka disimpulkan hipotesis 1 , hipotesis 2 dan hipotesis 3 di tolak karena t hitung $<\mathrm{t}$ tabel dan nilai sig $>0.05$. 
Uji Signifikansi secara Simultan (FTest)

Uji statistik simultan dilakukan untuk menguji atau menunjukkan apakah semua variabel independen dapat diterima menjadi model penelitian terhadap variabel dependen secara simultan. Pengujian ini dilakukan dengan melakukan perbandingan antara nilai $\mathrm{F}_{\text {hitung }}$ dengan $\mathrm{F}_{\text {tabel }}$ dengan menggunakan tingkat kepercayaan $95 \%(\alpha=0.05)$ dan derajat kebebasan $(\mathrm{df})=(\mathrm{k}-1)(\mathrm{n}-\mathrm{k}) \mathrm{di}$ mana $\mathrm{k}$ adalah jumlah variabel dan $\mathrm{n}$ adalah jumlah sampel.

Formulasi hipotesis:

H0: Variabel current ratio, debt to equity ratio dan return on assets secara simultan tidak berpengaruh terhadap dividend payout ratio.

Ha: Variabel current ratio, debt to equity ratio dan return on assets secara simultanber pengaruh terhadap dividend payout ratio.Dasar pengambilan keputusannya sebagai berikut:

1. Jika $\mathrm{F}_{\text {hitung }}<\mathrm{F}_{\text {tabel, }}$, maka Ha ditolak dan $\mathrm{H} 0$ diterima.

Jika $\quad \mathrm{F}_{\text {hitung }}>\mathrm{F}_{\text {tabel, }}$ maka Ha diterima dan $\mathrm{H} 0$ ditolak.

2. Jika probabilitas signifikan $>0.05$, maka Ha ditolak dan $\mathrm{H} 0$ diterima. Jika probabilitas signifikan $<0.05$, maka Ha diterima dan $\mathrm{H} 0$ ditolak.

Hasil uji simultan variabel independen terhadap variabel dependen dengan menggunakan program SPSS 23 dapat dilihat melalui tabel dibawah ini:

Tabel 3 Hasil Uji F-Test

\begin{tabular}{ccc}
\hline Model & F & Sig \\
\hline $\begin{array}{c}\text { X1,X2,X3 } \\
\text { thd Y }\end{array}$ & 4.309 & 0.011 \\
\hline
\end{tabular}

Sumber : Data Olahan (2020)

Berdasarkan tabel 3, diperoleh nilai $F_{\text {hitung }}$ sebesar 4,309 dengan signifikansi 0,011. Oleh karena $\mathrm{F}_{\text {hitung }}=$
4,309> $\mathrm{F}_{\text {tabel }}=2,87$ maka H0 ditolak, yang berarti Ha diterima, yaitu terdapat pengaruh secara simultan antara current ratio, debt to equity ratio, dan return on assetsterhadap kebijakan dividen (dividend payout ratio) pada perusahaan property dan real estate yang tercatat di BEI pada periode 2015 sampai dengan 2017.

\section{Pengaruh Current Ratio (X) terhadap Dividend Payout Ratio (Y)}

Berdasarkan tabel 3, thitung untuk variabel $\mathrm{CR}$ sebesar 1,886>1,68957. Dengan demikian keputusannya sesuai dengan $t_{\text {hitung }}>$ $\mathrm{t}_{\text {tabel }}$ adalah Ha diterima dan $\mathrm{H} 0$ ditolak yang berarti current ratio (CR) berpengaruh terhadap dividend payout ratio. Hasil penelitian ini sejalan dengan penelitian Wahyuni (2018) menyimpulkan bahwa current ratio tidak berpengaruh terhadap kebijakan dividen karena tidak ada hubungan yang signifikan antara current ratio dengan kebijakan dividen, dan bertolak belakang dengan penelitian Sari, et al., (2016) menyimpulkan bahwa current ratio berpengaruh positif dan signifikan terhadap kebijakan dividen, sementara

Pengaruh Debt to Equity Ratio $\left(\mathrm{X}_{2}\right)$ terhadap Dividend Payout Ratio(Y)

Berdasarkan tabel 3, thitung untuk variabel DER sebesar -0,672 < 1,68957. Dengan demikian keputusannya sesuai dengan thitung $>$ $\mathrm{t}_{\text {tabel }}$ adalah Ha ditolak dan $\mathrm{H} 0$ diterima yang berarti debt to equtiy ratio (DER) tidak berpengaruh terhadap dividend payout ratio. Hasil penelitian ini bertolak belakang dengan penelitian dari Pamungkas (2017) juga menyatakan bahwa perusahaan lebih menyukai pembiayaan dengan modal sendiri daripada menggunakan dana dari pihak luar (hutang), karena hutang memberikan risiko yang tinggi. 
Pengaruh Return on Assets $\left(\mathrm{X}_{3}\right)$ terhadap Dividend Payout Ratio (Y)

Berdasarkan tabel 3, $\mathrm{t}_{\text {hitung }}$ untuk variabel ROA sebesar $1,345<$ 1,68957. Dengan demikian keputusannya sesuai dengan thitung $>$ $t_{\text {tabel }}$ adalah Ha ditolak dan $\mathrm{H} 0$ diterima yang berarti return on assets (ROA) tidak berpengaruh terhadap dividend payout ratio. Penelitian ini bertolakbelakang dengan penelitian yang juga dilakukan oleh Yudhanto dan Aisjah (2012), yang menyimpulkan hasil bahwa return on assets berpengaruh positif dan signifikan terhadap kebijakan dividen.

Pengaruh Current Ratio $\left(\mathrm{X}_{1}\right)$, Debt to

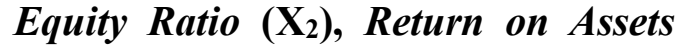
(X) terhadap Dividend Payout Ratio (Y)

Berdasarkan tabel 3, meskipun secara parsial setiap variabel tidak semua berpengaruh namun terdapat pengaruh secara simultan antara current ratio, debt to equity ratio, dan return on assetsterhadap kebijakan dividen pada perusahaan property dan real estate yang tercatat di BEI pada periode 2015 sampai dengan 2017. Hal ini dibuktikan dari diperolehnya nilai $F_{\text {hitung sebesar 4,309 dengan }}$ signifikansi 0,011. Oleh karena $F_{\text {hitung }}=$ $4,309>\mathrm{F}_{\text {tabel }}=2,87$ maka H0 ditolak, yang berarti Ha diterima.

\section{PENUTUP}

\section{Kesimpulan}

Berdasarkan hasil uji yang dilakukan oleh peneliti, maka kesimpulan dari penelitian ini adalah:

1. Secara parsial terdapat pengaruh antara current ratio terhadap dividend payout ratio yang terdaftar di Bursa Efek Indonesia tahun 2015-2017

2. Secara parsial tidak ada pengaruh antara debt to equity ratio terhadap dividend payout ratio yang terdaftar di Bursa Efek Indonesia tahun 2015-2017

3. Secara parsial tidak ada pengaruh antara return on asset terhadap dividend payout ratio yang terdaftar di Bursa Efek Indonesia tahun 2015-2017

4. Secara simultan terdapat pengaruh signifikan antara current ratio, debt to equity ratio, return on asset terhadap dividend payout ratio yang terdaftar di Bursa Efek Indonesia tahun 2015-2017.

\section{Saran}

Berdasarkan hasil uji yang dilakukan oleh peneliti, maka saran dari penelitian ini adalah:

1. Bagi perusahaan, disarankan agar pihak manajemen memperhatikan variabel yang mempengaruhi dividend payout ratio yakni dalam penelitian ini adalah current ratio dengan cara mengelola aktiva yang dimiliki perusahaan dengan baik. Karena besar kecilnya dividen yang dibagikan merupakan masalah yang penting bagi perusahaan.

2. Bagi Universitas Prima Indonesia, agar dapat memberikan referensi kepada peneliti lainnya.

3. Bagi investor, disarankan lebih memperhatikan laporan keuangan emiten seperti laba yang diperoleh, hutang, ketersediaan dana perusahaan.

4. Dari hasil Adjusted R Square dimana variabel dependen hanya dipengaruhi variabel independen sebesar 20,7\%, maka disarankan untuk peneliti selanjutnya menambahkan variabel lainnya. 
DAFTAR PUSTAKA

Atmoko, Y., Defung, F., \& Tricahyadinata, I. (2018). Pengaruh Return on Assets, Debt to Equity Ratio, dan Firm Size Terhadap Dividend Payout Ratio. Kinerja, 14(2), 103. https://doi.org/10.29264/jkin.v1 $4 \mathrm{i} 2.2486$

Hery. (2016). Analisis Laporan Keuangan Integrated and Comprehensive Edition (1st ed.). Bandung: Grasindo.

Husnan, S., \& Pudjiastuti, E. (2015). Dasar-dasar Manajemen Keuangan (7th ed.). Yogyakarta: UPP STIM YKPN. Muhammadinah., \& Jamil, M. A. (2016). Pengaruh Current Ratio, Debt to Equity Ratio, Total Asset Turnover dan Return on Asset Terhadap Dividen Payout Ratio pada Perusahaan Sektor Industri Barang Konsumsi yang Terdaftar di Bursa Efek Indonesia. I-Economics, 1(1), $1-20$.

Pamungkas, N., Rusherlistyani, \& Janah, I. (2017). Pengaruh Return on Equity, Debt to Equity Ratio, Current Ratio, Earning Per Share dan Investment Opportunity Set Terhadap Kebijakkan Dividen. Jurnal Analisa Akuntansi Dan Perpajakan, 1(1), 34-41.

Prihadi, T. (2019). Analisis Laporan Keuangan Konsep dan Aplikasi. Jakarta: PT Gramedia Pustaka Utama.

Sari, M. R., Oemar, A., \& Andini, R. (2016). Pengaruh Pertumbuhan Perusahaan, Ukuran Perusahaan, Earning Per Share, Current Ratio, Return On Equity dan Debt Equity Ratio Terhadap Kebijakan Dividen. Journal of Accounting, 2(2), 1-
19.

Sujarweni, V., W. (2019). Analisis Laporan Keuangan Teori, Aplikasi, dan Hasil Penelitian (11th ed.). Yogyakarta: Pustaka Baru Press.

Sukamulja, S. (2019). Analisis Laporan Keuangan Sebagai Dasar Pengambilan Keputusan Investasi (1st ed.). Yogyakarta: ANDI Yogyakarta.

Wahyudiono, B. (2014). Mudah Membaca Laporan Keuangan. Jakarta: Raih Asa Sukses.

Wahyuni, S. F., \& Hafiz, M. S. (2018). Pengaruh CR, DER dan ROA Terhadap DPR pada Perusahaan Manufaktur di BEI. Jesya (Jurnal Ekonomi \& Ekonomi Syariah), 1(2), 25-42. https://doi.org/10.36778/jesya.v $1 \mathrm{i} 2.18$

Yudhanto, S., \& Aisjah, S. (2012). Pengaruh Net Profit Margin, Return on Asset, Return on Equity, Earning Per Share Terhadap Kebijakan Dividen (Studi pada Perusahaan Manufaktur yang Terdaftar di Bursa Efek Indonesia). Jurnal Ilmiah Mahasiswa FEB Universitas Brawijaya, 1(2), 114. 